\title{
Reduction of Non-CO2 Gas Emissions Through The In Situ Bioconversion of Methane
}

\author{
DE-FG-02-03ER83605
}

\author{
Andrew R. Scott \\ Donna F. Balin \\ Altuda Energy Corporation \\ San Antonio, Texas \\ andrew@altuda.com \\ Biswarup Mukhopadhyay \\ Bioinformatics Institute, Virginia Tech \\ Blacksburg, Virginia \\ biswarup@vt.edu
}




\section{Table of Contents}

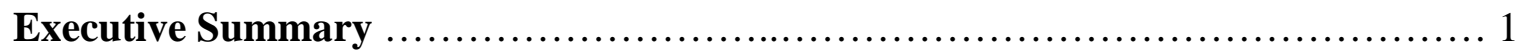

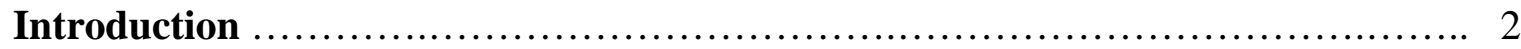

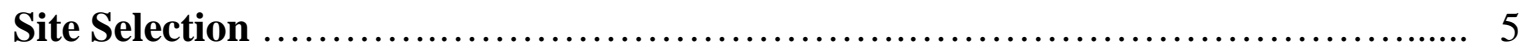

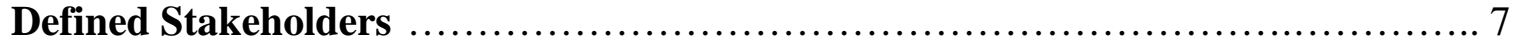

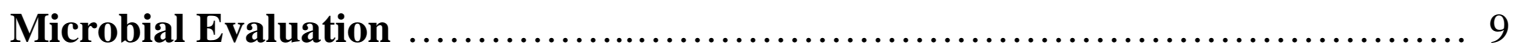

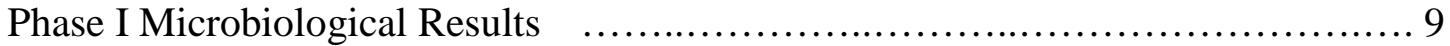

Biological Oxidation of Methane Anaerobic................................... 13

Phase II Microbial Results.......................................................... 16

Development of Stable AMO Enrichments...................................... 21

Evaluation of Enrichments for Methane Oxidation Potential........................ 23

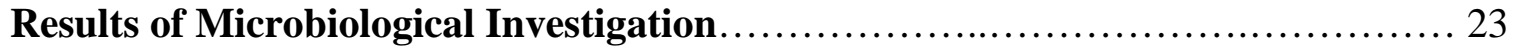

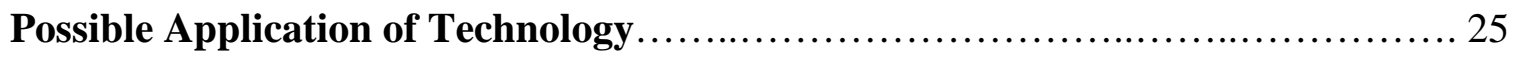

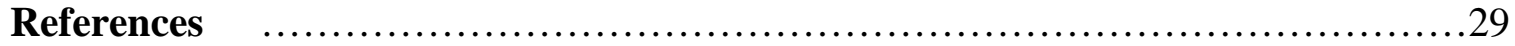

\section{FIGURES}

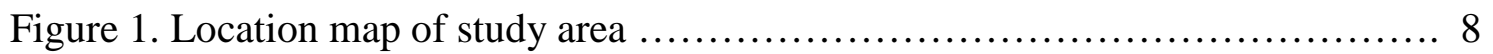

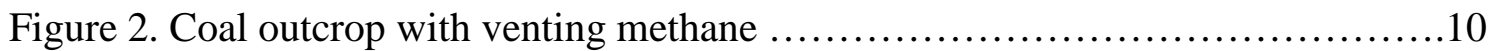

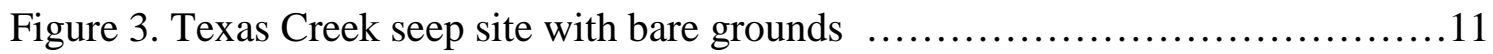

Figure 4. Detailed image of methane seep in creek .................................11

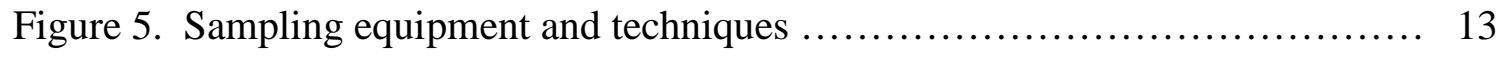

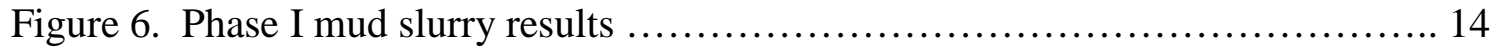

Figure 7. Phase I results of soil core samples .................................... 14

Figure 8. Methane seeps in snow, Texas Creek ................................ 16

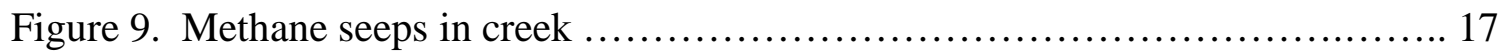

Figure 10. Methane and H2S seeps western outcrop belt ......................... 18

Figure 11. Oil and water seeps Southern California ............................... 19

\section{TABLES}

Table 1. Major sampling locations and dates ...................................... 19

Table 2. List of microbes identified during seep study ............................. 24 


\section{EXECUTIVE SUMMARY}

The primary objectives of this research were to seek previously unidentified anaerobic methanotrophs and other microorganisms to be collected from methane seeps associated with coal outcrops. After these microorganisms have been collected, they would be, identified, cultured, and applied to underground mines or areas where methane seeps occur. They could reduce methane seepage along coal outcrop belts and in coal mines, preventing hazardous explosions. Depending upon the types and characteristics of the methanotrophs identified, it may be possible to apply the microbes to other sources of methane emissions, which include landfills, rice cultivation, and industrial sources where methane can accumulate under buildings. Finally, the microbes collected and identified during this research could also have useful applications in the chemical industry, as well as in a variety of microbial processes.

Sample collection focused on the South Fork of Texas Creek located approximately 15 miles east of Durango, Colorado. The creek is located near the subsurface contact between the coal-bearing Fruitland Formation and the underlying Pictured Cliffs Sandstone. The methane seeps occur within the creek and in areas adjacent to the creek where faulting may allow fluids and gases to migrate to the surface. These seeps appear to have been there prior to coalbed methane development.

In our investigations we screen more than 500 enrichments and were unable to find a convincing case of anaerobic methane oxidation. In all cases, as evident from visual and microscopic observations, the early stage enrichments contained microbial cells. However, as the levels of the readily substrates that were present in the environmental samples were extensively lowered through serial transfers, the numbers of cells in the enrichments sharply dropped and finally these were eliminated. While the results were disappointing we acknowledge that anaerobic methane oxidizing (AOM) microorganisms are predominantly found in marine habitats and grow poorly under most laboratory conditions. 


\section{INTRODUCTION}

Carbon dioxide is the dominant greenhouse gas generated from anthropogenic sources, although methane also has a significant impact on global warming. Methane has a global warming potential approximately 21 times greater than carbon dioxide and is estimated to have contributed about 20 percent of the incremental infrared greenhouse gas forcing since 1850 (Houghton, et al., 1996). The Intergovernmental Panel of Climate Change (IPCC) estimated total methane emissions from all sources to range from 451 to 570 million tons (22.0 to $27.8 \mathrm{Tcf}$ ) which equals or exceeds the current natural gas consumption in the United States (IPCC, 1995). Concerns over global climate change associated with anthropogenic greenhouse gas emissions have resulted in a heightened interest in developing cost-effective means of mitigating these emissions.

The relative global warming potential of methane is significantly higher than that of carbon dioxide, indicating that the reduction of methane emissions on a ton-by-ton basis will have a much larger impact on climate change than reductions in carbon dioxide. Additionally, methane has a relatively short lifetime of approximately 12 years compared to a 120-year lifetime of carbon dioxide. Because of the global warming potential of methane and the short lifetime, programs and policies that target reductions in methane emissions have the potential to mitigate the rate of climate change at a faster rate than those that target reductions in emissions of carbon dioxide and other longerlived greenhouse gases.

The primary sources of anthropogenic methane emissions include coal mining, landfills, the oil and natural gas industry and animal wastes. Methane emissions from coal mines, landfills, and shallow, unmineable coal seams present additional dangers if gases accumulate in explosive quantities. Worldwide emissions from the coal industry in 1999 were estimated to be $24 \mathrm{Mt}$ (1.2 Tcf) and are expected to increase to $31 \mathrm{Mt}$ (1.5 Tcf) by the year 2010 (Sapoundjiev et al., 1999). Of these totals, nearly 14 million tons (0.7 Tcf) of methane are released from coal mine ventilation shafts alone (Sapoundjiev et al., 1999) even though the concentration of methane in the vented air is very low (1 $\mathrm{v} / \mathrm{v} \%)$. Surface mining and transportation of coal were estimated to contribute an 
additional 2.7 to 8.8 million tons (47 to $157 \mathrm{Bcf}$ ) of additional emissions (Kruger and Schultz, 1996).

Microbes may be transported 30 miles or more basinward from coal outcrops through permeable coal seams where they can convert the coal into secondary biogenic methane (Scott et al., 1994). The secondary biogenic methane generated from microbial activity and thermogenic methane generated during the burial and thermal maturation of the coal are sorbed on the microporous structure of the coal. More methane can be sorbed onto the coal at higher pressures and burial depths. Locally, biogenic gases may be formed very near the surface close to the coal outcrop, and small changes in pressure, possibly due to seasonal variations in precipitation rates, may result in methane desorption from the coal resulting in temporary methane seeps. Methane migrating upwards from deeper parts of the basin via faults or other permeable pathways can form long-lived methane seeps that may persist for tens or even a hundred years in the same locality. Once major concern of local stakeholders in the San Juan Basin of Colorado and New Mexico is the possibility of the migration of additional methane desorbed from the coal surfaces towards the Fruitland coal outcrop belt where many residences are located.

Methane is released from the coal when the pressure is reduced during coal mining operations and poses a high risk to coal miners. To prevent accumulation of explosive quantities of methane, operators pump air through the mines, and the mine air, which includes methane, is vented to the atmosphere. Although the recovery of methane from coal mining operations and landfills has progressively become more common and important for the removal of methane as a greenhouse gas, these processes are driven economically. If the gas present in coal seams and/or landfills does not accumulate in economic quantities, the methane recovery operations are either not initiated or may be ceased if natural gas prices do not support such operations. In either event, the methane continues to be released to the atmosphere.

Presently known methanotrophs (methane-consumers) are common in oxygenrich environments, and many researchers have attempted to find methanotrophs that are capable of consuming methane anaerobically. However, it was only recently that anaerobic methanotrophs were isolated from a marine environment (Boetius et. al, 2000); sulfate reduction provided the electron acceptors for methane oxidation, demonstrating 
the possibility of anaerobic methane oxidation. Coming into this project, we believed that anaerobic methane oxidation might also occur in terrestrial environments. Therefore, ne of the primary objectives of this project was to conduct a sampling program in locations (coal-bearing geologic systems) previously not identified or even considered for the collection of aerobic or, in particular, anaerobic methanotrophs. These microbes would have a unique genetic signature that might potentially have broad applications in other areas

Part of our research performed during Phase I confirmed that there are numerous methane seeps in the northern part of the San Juan basin that may contain methanotrophs. In several parts of the San Juan Basin, houses and property were purchased by BP-Amoco and subsequently destroyed because the methane concentrations approached explosive levels. There are concerns locally and state-wide that coalbed methane production deeper in the basin that potentially could result in the release of additional methane to the outcrop as the coal reservoirs are depressurized. Therefore, developing a microbial system that can anaerobically consume methane near the surface before it is released to the atmosphere could significantly reduce the future release of greenhouse gases and improve public safety.

We believe that previously unidentified methanotrophs collected from methane seeps associated with coal outcrops, from surface mines located in gas-prone areas, and from underground mines can be collected, identified, cultured, and applied to underground mines. These organisms would reduce methane seepage at the outcrop and in coal mines, preventing hazardous explosions. Naturally occurring methanotrophs associated with coal would most likely have genetically adapted to the coal or coaly soils and would be more efficient in reducing methane emissions. Depending upon the types and characteristics of the methanotrophs identified, it may be possible to apply the microbes to other sources of methane emissions, which include landfills, rice cultivation, and industrial sources.

Developing methods and new technology to mitigate methane emissions in coalbearing areas as well as hydrogen sulfide generation has multiple economic benefits including: (1) the reduction of methane and other greenhouse gas emissions that contribute to the global warming potential; (2) improved mine safety and prevention of 
costly shut downs of underground mining operations when hydrogen sulfide is encountered; (3) the reduction of explosion potential in underground mining operations and areas of high methane seepage in close proximity to residential and commercial properties; (4) reduction in the rate of methane seeps at the outcrop, lowering the expenditure of taxpayer dollars to monitor methane flux; and (5) reduction of methane seeps that may also prevent the abandonment of coalbed methane wells near the outcrop, a situation which would otherwise decrease natural gas production and corresponding state and local tax revenues.

\section{SITE SELECTION}

The San Juan Basin in Colorado and New Mexico is unique in that some methane seeps have existed for over 100 years, whereas other seeps are reported to have formed more recently. There are concerns that as coal reservoir pressures in the deeper parts of the basin decline from coalbed methane production, methane will be release (desorbed) from the coal and migrate to the outcrop and form new methane seeps. Long-lived methane seeps may contain anaerobic methanotrophs in the San Juan and other coalbearing basins. A series of methane capture wells located on Southern Ute Tribal land were visited during the course of this research. These wells were drilled close to the edge of the basin in an attempt to capture the upward migrating coal gases before they reached the outcrop belt. At the time of the study the wells were shut in and not collecting and transporting methane to market.

A study performed by the Bureau of Land Management on methane seeps in the San Juan Basin of Colorado and New Mexico indicates that significant quantities of methane are being emitted from the Fruitland coal outcrop. Five separate models were designed to predict methane seepage fluxes based on coal permeabilities ranging from 1 to $100 \mathrm{md}$. Estimates of the annual methane released to the atmosphere ranged from 239 to 39,515 tons of methane per mile of outcrop per year (BLM White Paper, 1999). Taking a "best guess" of the average methane seep of 10,679 tons per mile per year and assuming that methane seeps from only 45 miles of the 90 mile outcrop belt in Colorado, then over 480,000 tons of methane are released to the atmosphere each year; note that this 
estimate is from the northern part of just one basin in Colorado alone. Therefore, naturally occurring methane seeps from coal-bearing basins across the United States probably contribute more to total methane emissions than previously recognized.

Although additional methane seep areas were previously identified in Utah and the Raton Basin of Colorado, the decision was made to focus on the Texas Creek area of the San Juan Basin that was the focus of the initial phase of the research (Figure 1). During the research we realized that Southwestern Colorado was under extreme drought conditions, with an average precipitation rate of only 1.7 inches between 2002 to 2007 compared to an average of 19.1 inches between 1900 and 1991. In 2003 when this study was initiated, the annual precipitation was only 0.06 inches in Durango, Colorado. Drought conditions presented unique conditions for sampling methane seeps, because lower water flow rates may concentrate the microbial populations in smaller areas making sample collection more fruitful. Higher precipitation rates returned towards the end of the study, we were able collect additional microbes to determine whether or not microbial populations might fluctuate during climate changes.

The location of the methane seeps appears to be controlled by faulting in the area since the bare-grounds of dead vegetation that marks many seeps is very linear in nature. The methane seeps migrate laterally over time to different areas forming new bare spots, but the linear nature of the seeps is still obvious in many methane seep locations. Bifurcation of aspen tree trunks is a sign of stress, and these stress indicators can be dated from tree ring analyses. Preliminary tree-ring age dating results from research performed by BP-Amoco indicate that the methane seeps have been in the area for many decades. We can use the trunk bifurcation in aspen trees to locate new methane seeps in some areas. Local ranchers and families with residences along Texas Creek and the associated valley were contacted while searching for additional seep sites. Additional seep areas were found south of Texas Creek along the valleys shown in Figure 1.

At least some of the methane probably derived from updip migration along fault planes, but we also believe that some additional methane is generated locally by methanogenic microbes in the coal. The boundary between the lowermost Fruitland coal seams and the underlying Pictured Cliffs Sandstone appears to coincide with the location of Texas Creek. Therefore, meteoric water transported through Fruitland coals located 
north of County Road 502 (Figure 1a) probably contains organic material that is readily converted into methane in the subsurface coals seams beneath Texas Creek. The methane is probably dissolved in coal groundwater and migrates to stream valleys where it exsolves from the formation water and seeps to the surface. Methanotrophic microbes consume some of the methane before it reaches the surface, but the rate of methane flux is greater than the methanotrophic microbe consumption rates.

Recent research performed on methane seeps on behalf of major oil and gas operators indicated that the amount of methane seeping from the Texas Creek site is significant and is one of the most active seeps in the basin. The estimated methane flux between the SFTC site and Pine River (about three miles) has dropped from 5,200 Mcfd in 2007 to approximately 1,950 Mcf/d in 2010 (1.9 Bcf per year to $0.71 \mathrm{Bcf}$ per year) partially due to an underground methane drainage abaetment program.

\section{DEFINED STAKEHOLDERS}

The primary stakeholders were BP-Amoco, the Southern Ute Indian Tribe, and the BHP Billiton San Juan Underground Coal Mine who took the Principal Investigator (small business) and microbiologist (Dr. Mukhopadhyay) to methane seeps in organicrich, coaly muds in river and stream valleys, as well as to coal outcrops that had methane seeping from fractures and cleats in the coals. Multiple field trips were conducted throughout the research and the site was revisited even after the contract expired. We also developed contacts were also developed within the Durango Field office of the Bureau of Land Management (BLM), and the Colorado Oil and Gas Conservation Commission (COGCC) in Denver, Colorado. The BLM and COGCC have spent millions of dollars over approximately the last five years to research and monitor methane seeps in the San Juan, Raton, and Piceance Basins. Additionally, BLM personnel offered to take project scientists to new methane seep areas during the second phase of the research effort, but given the time and expense to develop microbial enrichments, additional sites were not sampled. Part of the proposed research effort that was limited due to the time and expense required to culture enrichments was seeking anaerobic methanotrophs in deep gas wells associated with sulfate-rich waters. Anaerobic microbes have been collected 
from samples taken between 8,700 to 9,180 feet in the eastern United States (Balkwin et al., 1994), suggesting that microbes are probably more ubiquitous in sedimentary basins than previously recognized.

Other future stakeholders that would potentially come into play once the technology were confirmed would be any number of subsurface coal mines across the United States as well as localized seep occurrences in other basins. On a local level, residents with housing located near the margins of the San Juan Basin where methane seeps may become more active on or near their properties would certainly have a vested interest in applying this technology. Possibly a combination of an application of anaerobic methanotrophs at depth where oxygen contents are extremely low coupled with injection of aerobic methanotrophs at shallower depths would mitigate methane seeps at the surface.

A

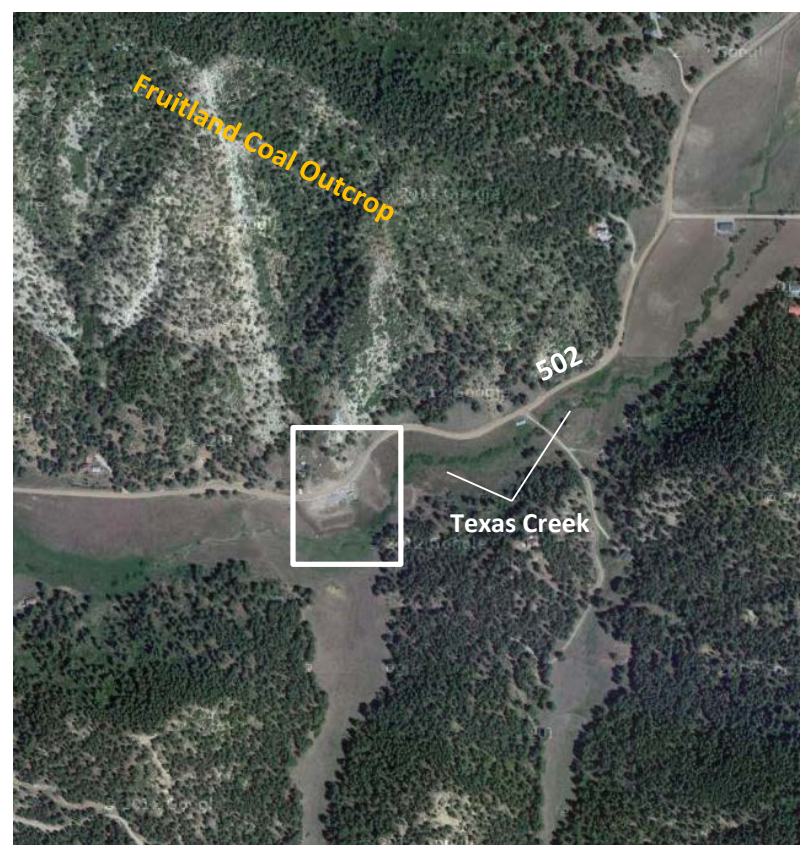

B

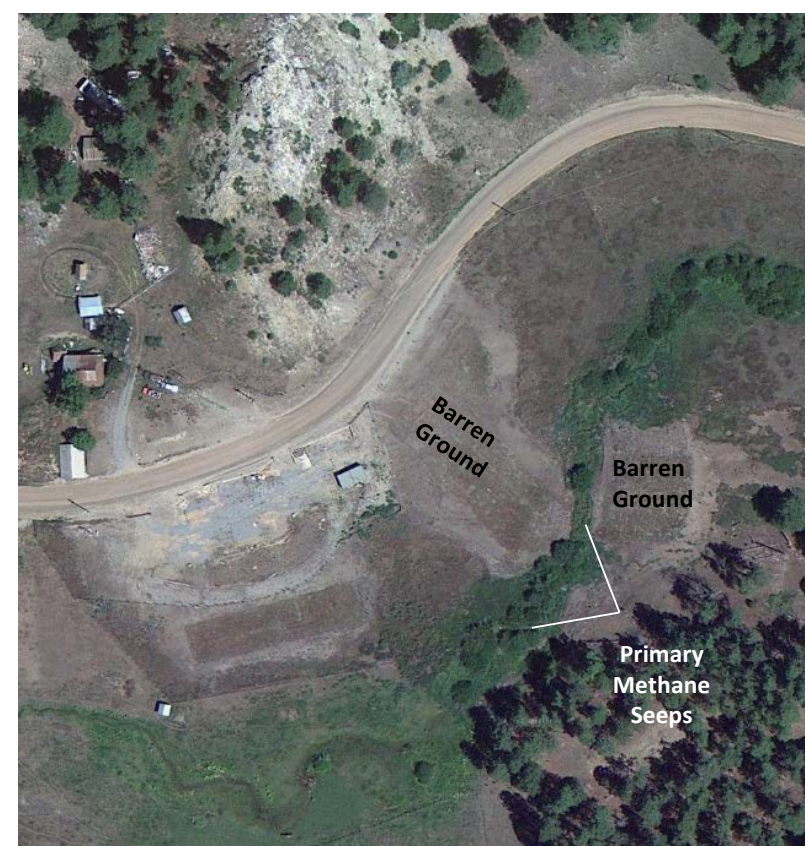

Figure 1. Location of study area (South Fork Texas Creek; SFTC) which is located on County Road 502 in La Plata County east of Durango, Colorado. (a) Numerous methane seeps are located along a one $\mathrm{km}$ stretch of Texas Creek, but the methane seeps sampled were near the foundation of a house that was torn down due to high levels of methane. (b) The methane seeps are widespread and large areas of barren grounds and microbial soils are abundant. The small building and a methane collection system were established approximately 18 months after the conclusion of this study in 2007 to carefully monitor the rate of methane emissions. 


\section{MICROBIOLOGICAL EVALUATION}

The ultimate goal of the Phase I and Phase II research was to develop technology for the in situ bioconversion of non- $\mathrm{CO}_{2}$ greenhouse gases with a focus on methane due to the potentially larger impact on global warming. Our goal was to develop protocols for injecting anaerobic methanotrophs, other microbes, and/or nutrients into a methane seep area or in front of coal mining areas during a Phase III field test.

\section{$\underline{\text { Phase I Microbiological Results }}$}

Phase I of the research project was designed to identify coal-bearing areas that have a high probability of finding methanotrophic bacteria, to develop sample collection protocol to collect anaerobic methanotrophs and other microorganisms from terrestrial environments, and to better understand the hydrogeologic factors affecting the location of methane seeps and associated methanotrophic microbes. Additionally, we were very successful at obtaining industry support during Phase I that allowed reconnaissance of potential seep areas. Most methane seeps are located on private land, so microbial sampling could not have taken place without the support of industry stakeholders/landowners.

An innovative anaerobic sample collection procedure was developed by researchers at Virginia Tech, and samples collected at methane seep localities were found to contain methanotrophs. These methane-eating microbes are actively consuming methane in the laboratory. Therefore, we believe that the microbiological and hydrogeological results of the Phase I research effort successfully demonstrated the feasibility of collecting and anaerobic microbes from methane seeps and that these microbes can be utilized to reduce methane greenhouse gas emissions from coal mines and coal outcrops. We also realized that application of bioconversion of non- $\mathrm{CO}_{2}$ gas technology can be applied to shallow methane seeps in areas that pose a danger to local communities and businesses.

Multiple trips to methane seeps were undertaken to first identify and study the methane seep areas and then to develop sampling techniques to collect methanotrophic microbes. Our first reconnaissance trip was followed by a sample collection trip that 
utilized an innovative technique for collecting anaerobic samples. We also contacted the Bureau of Land Management (BLM) in Durango, Colorado, and the Colorado Oil and Gas Conservation Commission (COGCC) who have spent considerable time, effort, and money to collect data on methane seeps in the northern San Juan Basin.

We collected soil core samples from the western margin of the basin on mountainous Southern Ute Indian Tribal Land. A number methane seeps were noted coming from fractures, joints and cleats in coal outcrops exposed along arroyos (Figure 2), but the sampling effort was made on soil core samples rather than on the coal outcrop. We also decided to focus our sample collection efforts in the northern San Juan Basin at the BP-Amoco Texas Creek site, because the area appeared to have more extensive and long-lived methane seeps than other areas. The site was characterized by two types of methane seeps (Figures 2, 3 and 4,b). One seep covered a relatively large area and was characterized by the presence of paraffinic earth comprised of microbial remains; this type of seep occurs generally along lineaments and is probably fault controlled. The second type of seep is focused along stream beds where methane could be seen bubbling in standing water (Figure 4a, b). Samples were collected from both types of seeps

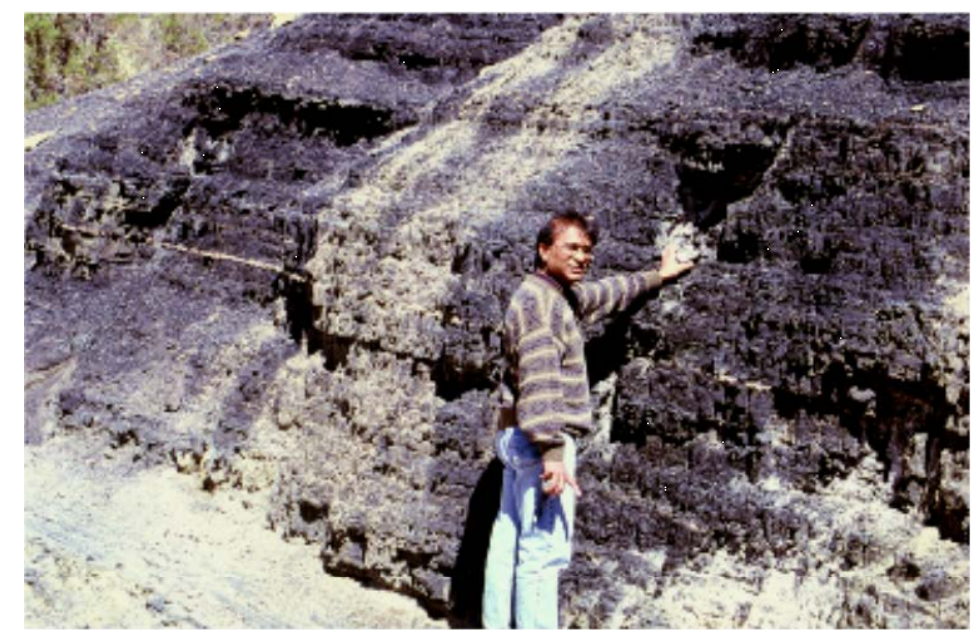

Figure 2. Coal outcrop with methane venting from fractures and cleats in the coal. 


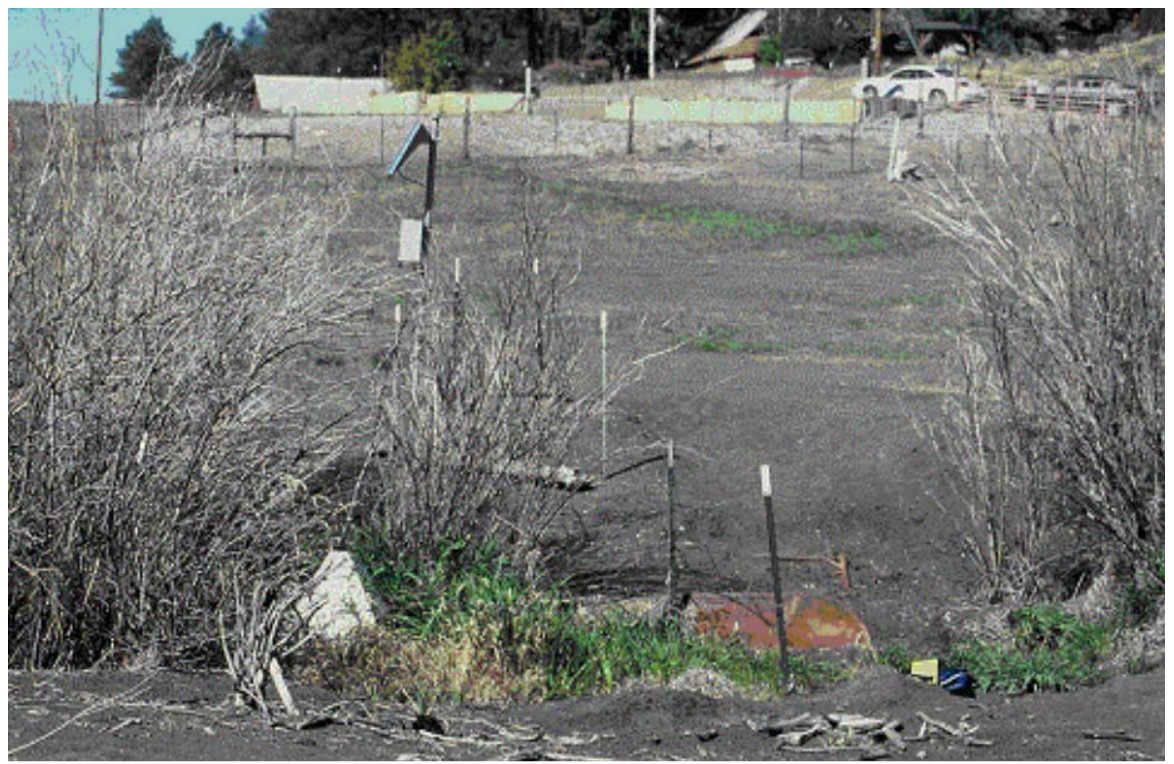

Figure 3. BP-Amoco Texas Creek seep site. Vegetation was killed by methane seepage and paraffinic hardpans, consisting of the microbial remains, formed in the area. BP-Amoco purchased the property from the landowner, because the methane seeps posed an explosive hazard. Note the Colorado Oil and Gas Conservation Commission methane flux equipment at the site.

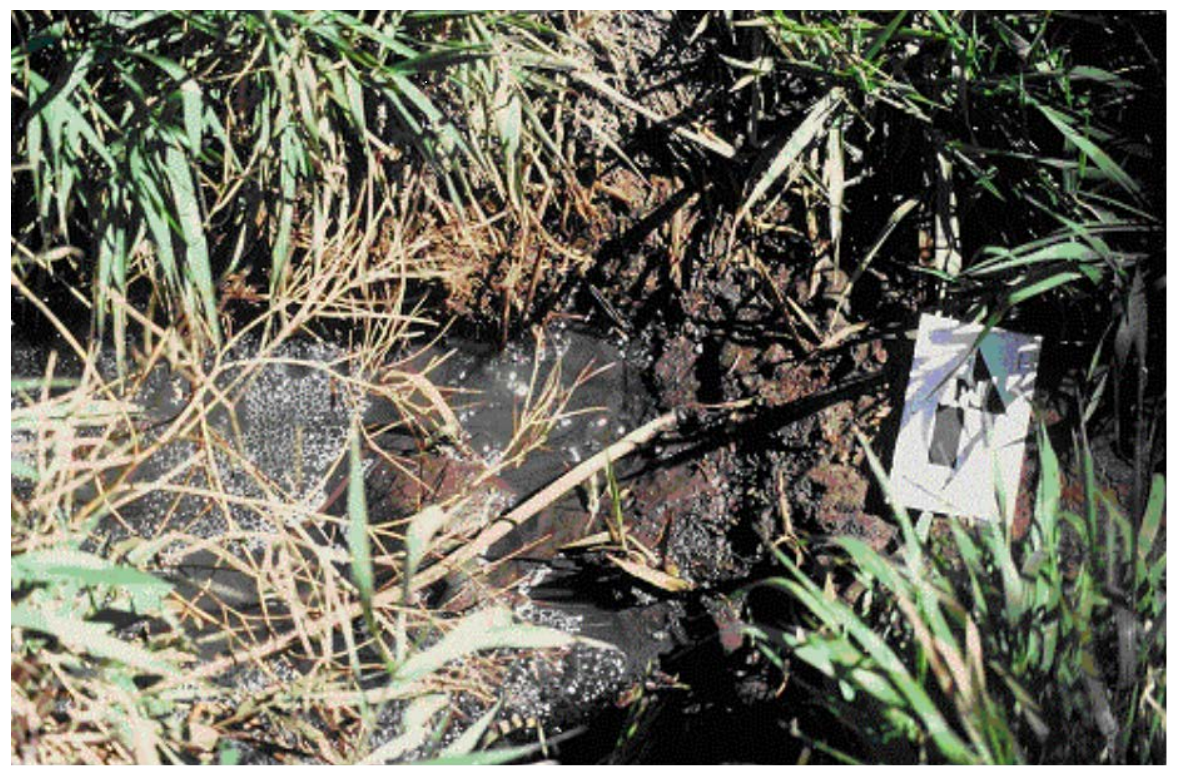

Figure 4. Detailed view of one of several methane seeps at Texas Creek. Scale is approximately 4 inches in length. The Durango area is in a severe drought situation so that water levels are at historic lows and methane could be heard bubbling in water below hardened soil crusts along the creek. 

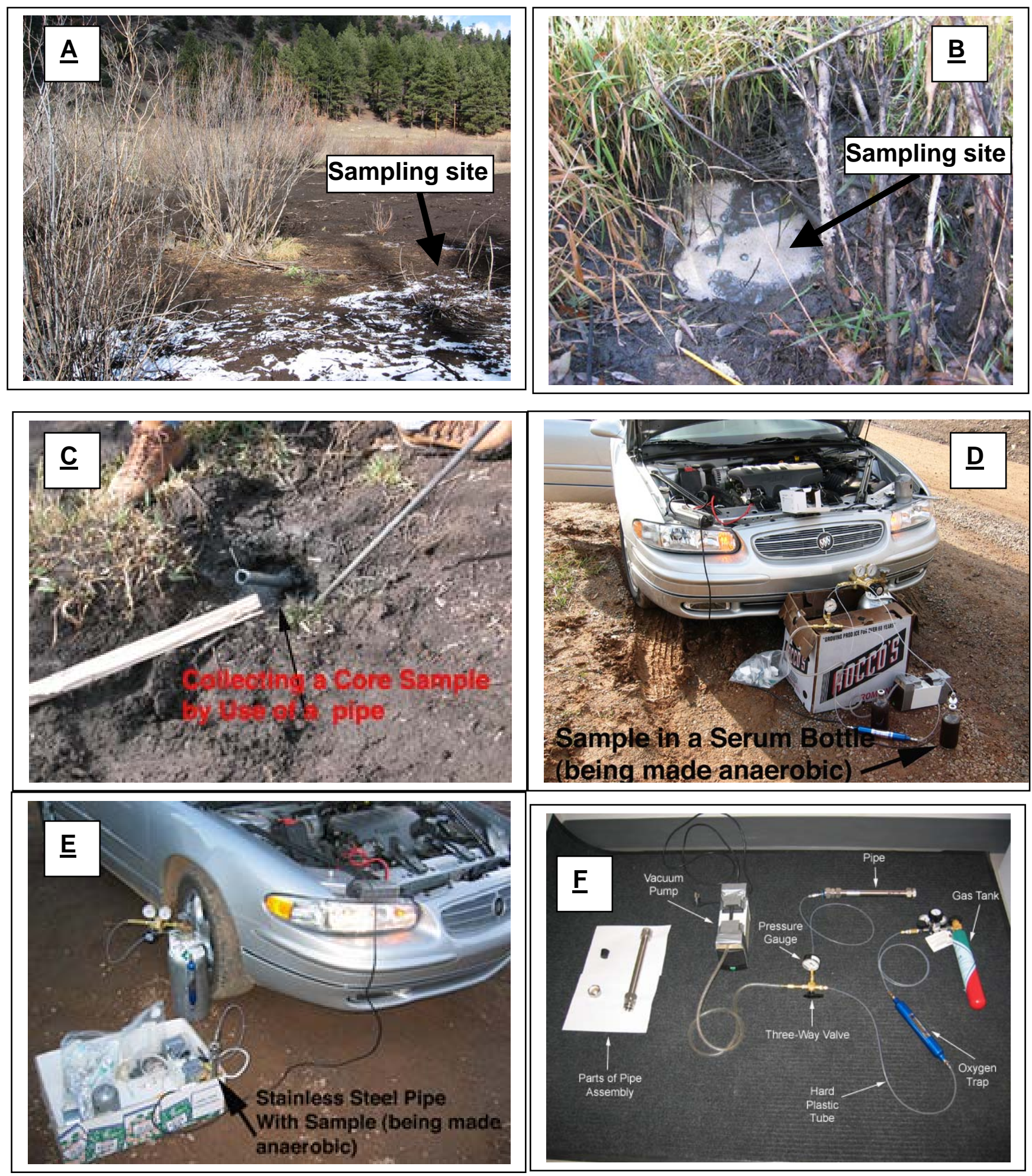

Figure 5. (a) BP-Amoco Texas Creek methane seep site (b), active methane seep and sample collection site, (c) soil core collection with pipe (d) serum bottle being made anaerobic, (e) soil samples in pipe being made anaerobic, and (f) detailed view of anaerobic sampling system. 
The major focus of our Phase I research was the anaerobic oxidation of methane. Therefore, developing the appropriate protocol for collecting anaerobic samples from methane seeps under variable conditions was a critical part of the Phase I research. Even trace amounts of oxygen in the system can support aerobic methanotrophs, so great care must be taken to assure that the samples are completely anaerobic. Researchers at Virginia Tech, under the direction of Dr. Muhopadhyay, designed a system to collect microbes from the methane seeps under anaerobic conditions. These techniques were used for the preservation and transportation of the field samples

The water in Texas Creek was restricted to small pockets of water left in muddy depressions, because of the drought conditions. Water in the creek was derived from springs whose water probably originated from deeper in the basin. The methane bubbled out constantly out of the muddy pockets at high rate thereby giving a foamy appearance to the water surface (Figures 4 and 5a). We collected slurry of mud from such a hole in serum bottles, and then used a vacuum pump system and supply of nitrogen, to make the contents of these bottles anaerobic and to keep them under a nitrogen atmosphere (Figure 5d). We also collected soil core samples from the surface seeps (Figure 13A). For this purpose we used a pipe (Figure 5C). The core soils were placed in pipes and made anaerobic and placed under nitrogen atmosphere as shown in Figure 5E. The pipes and bottles were then transported to the Virginia Bioinformatics Institute at the Virginia Tech and stored at $4{ }^{\circ} \mathrm{C}$.

\section{$\underline{\text { Biological oxidation of methane under anaerobic conditions }}$}

The sampling procedures developed for this project provided excellent quality samples that could be evaluated for methane oxidizing microorganisms. During the Phase I research we tested five samples collected from the site shown in Figures 3, 4 and 5 and the results clearly showed that our Phase II work had the potential to lead to the isolation of anaerobic methane oxidizers. Therefore, the Phase I research has

demonstrated the feasibility of isolating anaerobic methane oxidizers so that they can be applied to reducing non- $\mathrm{CO}_{2}$ greenhouse gas emission in coal mines and coaly outcrops. Soil core samples from the Southern Ute Tribe’s land are currently being processe 
The results from experiments performed on the mud slurry collected at the BPAmoco Texas Creek site (Figure 5b) are shown in Figure 6. Approximately, $50 \mathrm{ml}$ of mud slurry, with and without supplements of sodium sulfide (2 mM) and sodium sulfate (30 mM), was incubated anaerobically inside a $160 \mathrm{ml}$ serum bottle under a gas atmosphere composed of methane, $\mathrm{CO}_{2}$ and nitrogen at partial pressures of $30 \mathrm{kPa}, 42$ $\mathrm{kPa}$ and $168 \mathrm{kPa}$, respectively. The total pressure of the system was $240 \mathrm{kPa}$. The headspace gas was assayed for methane levels at regular intervals by use of a gas chromatograph. We found that when sulfate was not used as a supplement, the methane level in the head space gas increased upon incubation (upper curves on Figure 6). This observation was due to either desorption or production of methane. However when

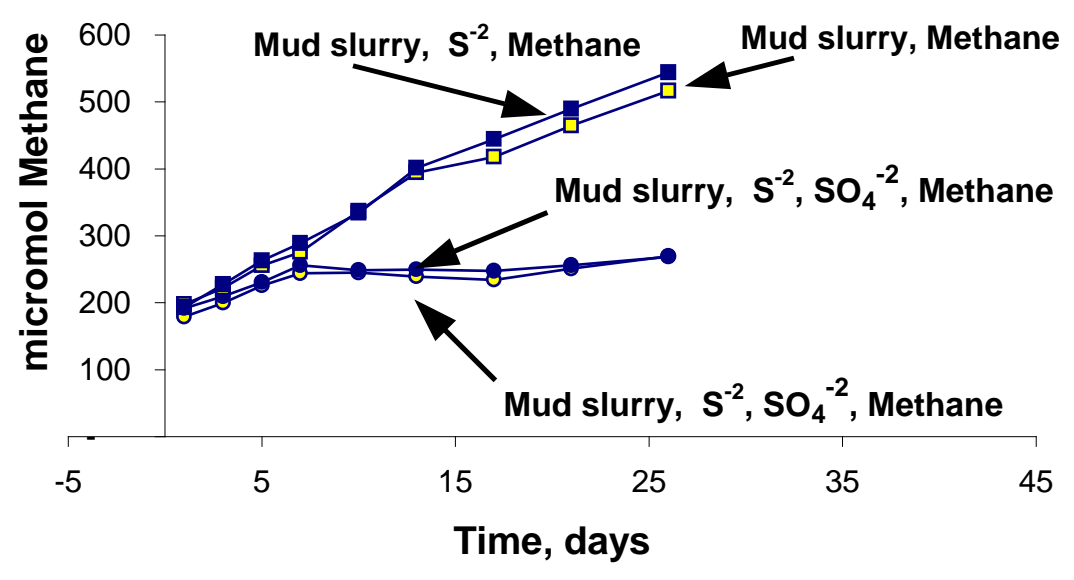

Figure 6. Results of experiments performed on mud slurry samples collected from Texas Creek. The presence of sulfate in the samples promoted anaerobic methane oxidation

sulfate was added to the mixture, after an initial increase the methane level became constant (lower curves on Figure 6). The initial rise in methane concentrations was due to the release of or production of methane in the samples. However, within seven days a methane oxidizing population developed and their activities prevented further accumulation methane.

Similar experiments were performed on soil core samples collected from the barren hardground shown in Figure 5a. Approximately $10 \mathrm{~g}$ of soil core samples were incubated 
with $50 \mathrm{ml}$ of freshwater medium or high salt medium (Balch and Wolfe, 1976) under the gas atmosphere described in the previous experiment. Additionally, the tests were performed in the presence or absence of added sodium sulfide (2 mM) and sodium sulfate (30 mM). The results shown in Figure 7 indicate that the soil sample did not produce much methane. However, the level of methane was lowered in the presence of sulfate, only when a high salt environment (high $430 \mathrm{mM} \mathrm{NaCl}$ and $50 \mathrm{mM} \mathrm{MgCl}_{2}$ concentrations) was provided. In summary, we have already developed the methods and inoculum sources for preparing enrichments for anaerobic methane oxidizers during the Phase I research leading up to believe that the Phase II would be successful.

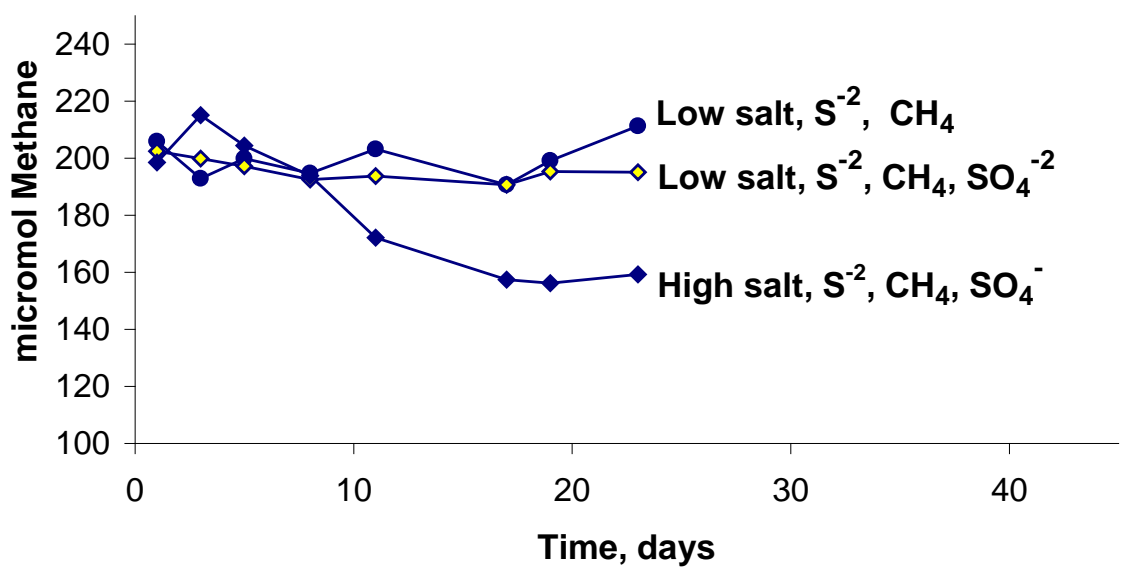

Figure 7. Results of experiments performed soil core samples collected from Texas Creek. 


\section{Phase II Microbiological Results}

The sampling protocol initiated during Phase I continued through Phase II and the end of the project. Samples that could harbor anaerobic methane oxidizers were carefully selected from the following locations: methane seep areas at the South Fork Texas Creek (SFTC) site, near Bayfield, CO, which is owned by BP-Amoco, Inc. (Figures 8 and 9) and some of the natural gas fields of The Southern Ute Indian Tribe near Ignacio, CO (Fig. 10); Chesapeake Bay Black Marsh in Virginia; a natural oil seep east of Los Angeles, California (Figure 11; Table 1). In addition to the major sampling trips, other trips were made to the area to speak with landowners and to scout the creek level and seep activity. These scouting trips took place periodically until 2009 even after the project was completed.
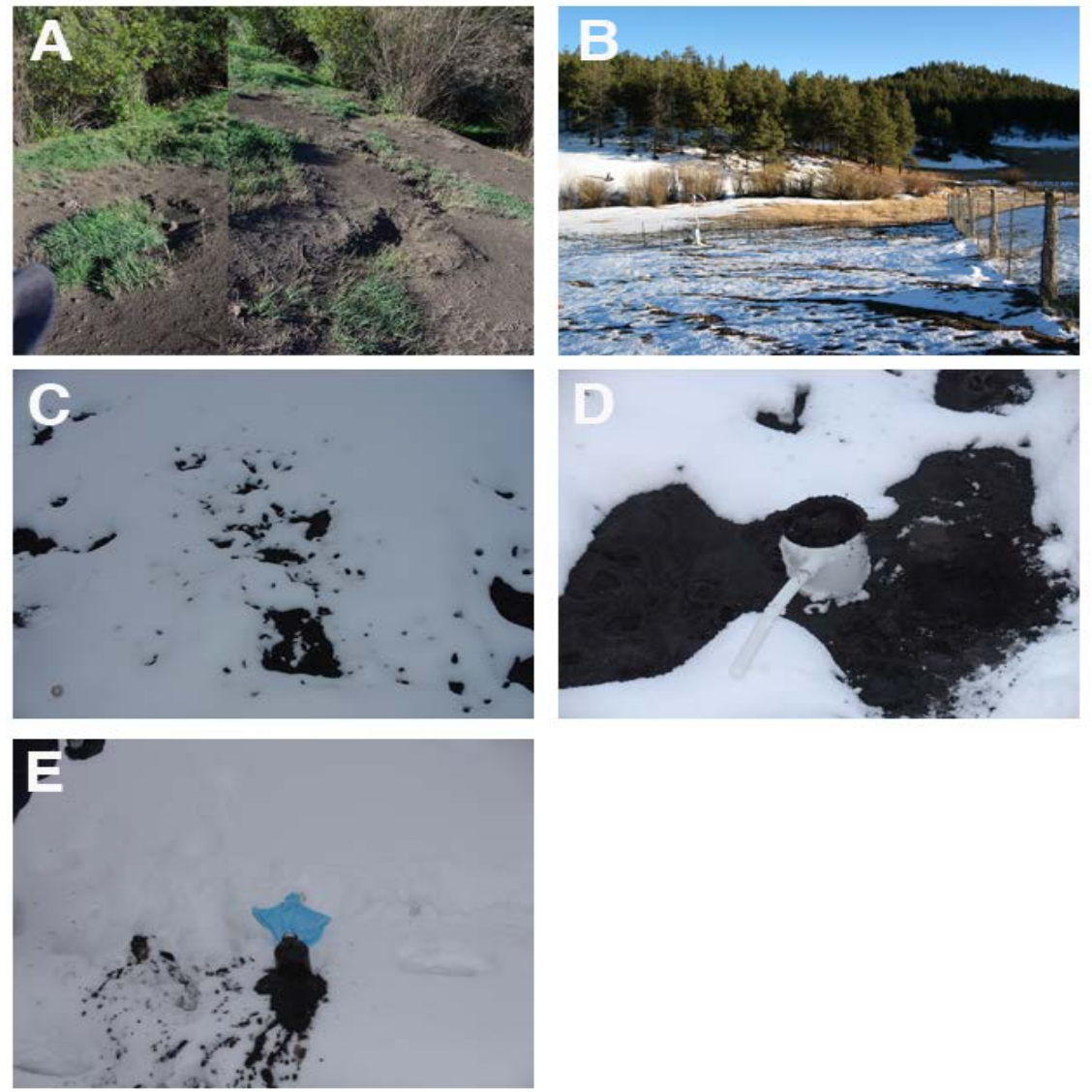

Figure 8. Methane seeps at South Fork, Texas Creek (SFTC) 

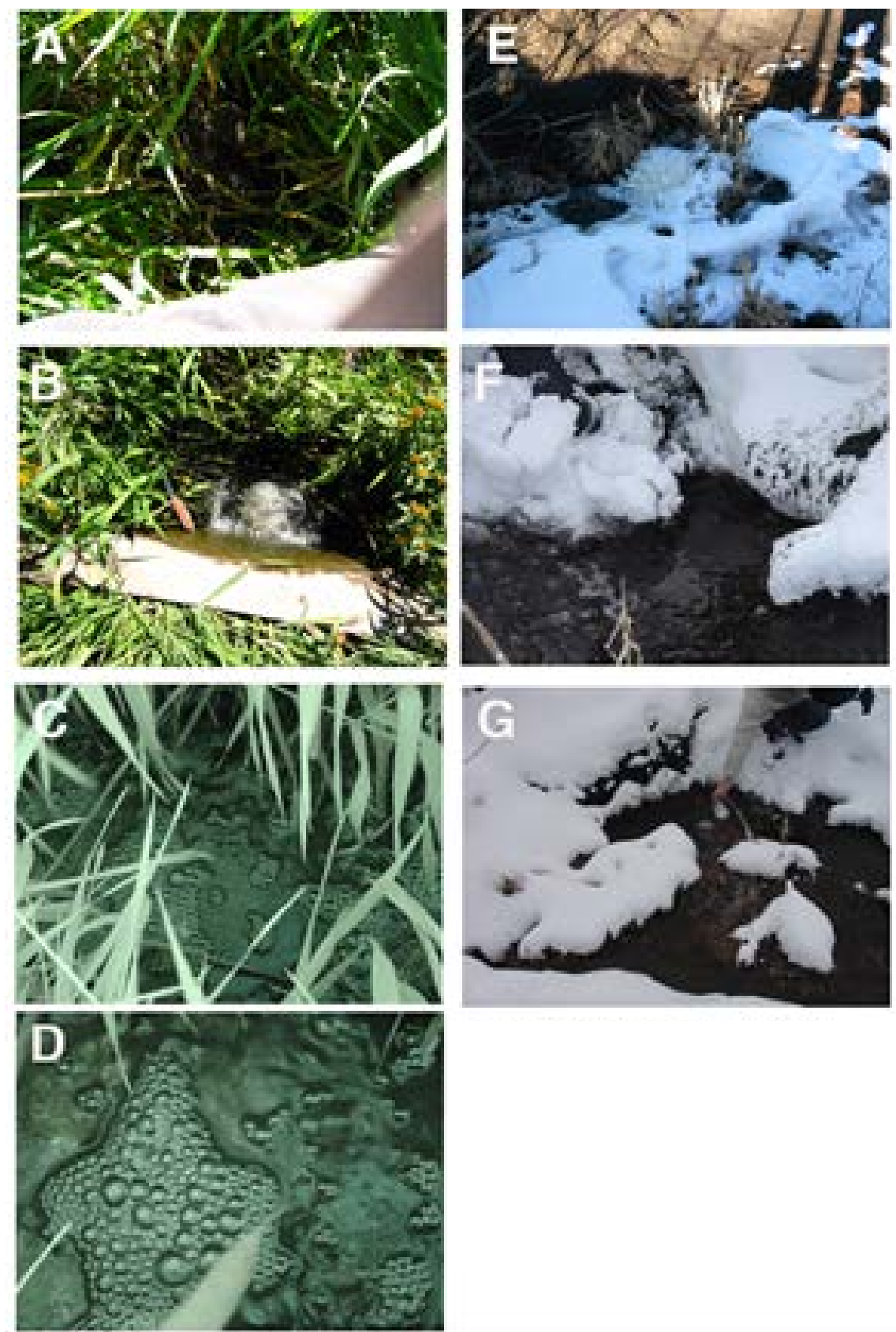

Figure 9. Methane seeps at South Fork, Texas Creek (SFTC) within the creek bed. Water flow in the stream was very low during the 2003-2004 season, but water flow increased as precipitation increased. The southwestern part of Colorado is still in a drought situation. 

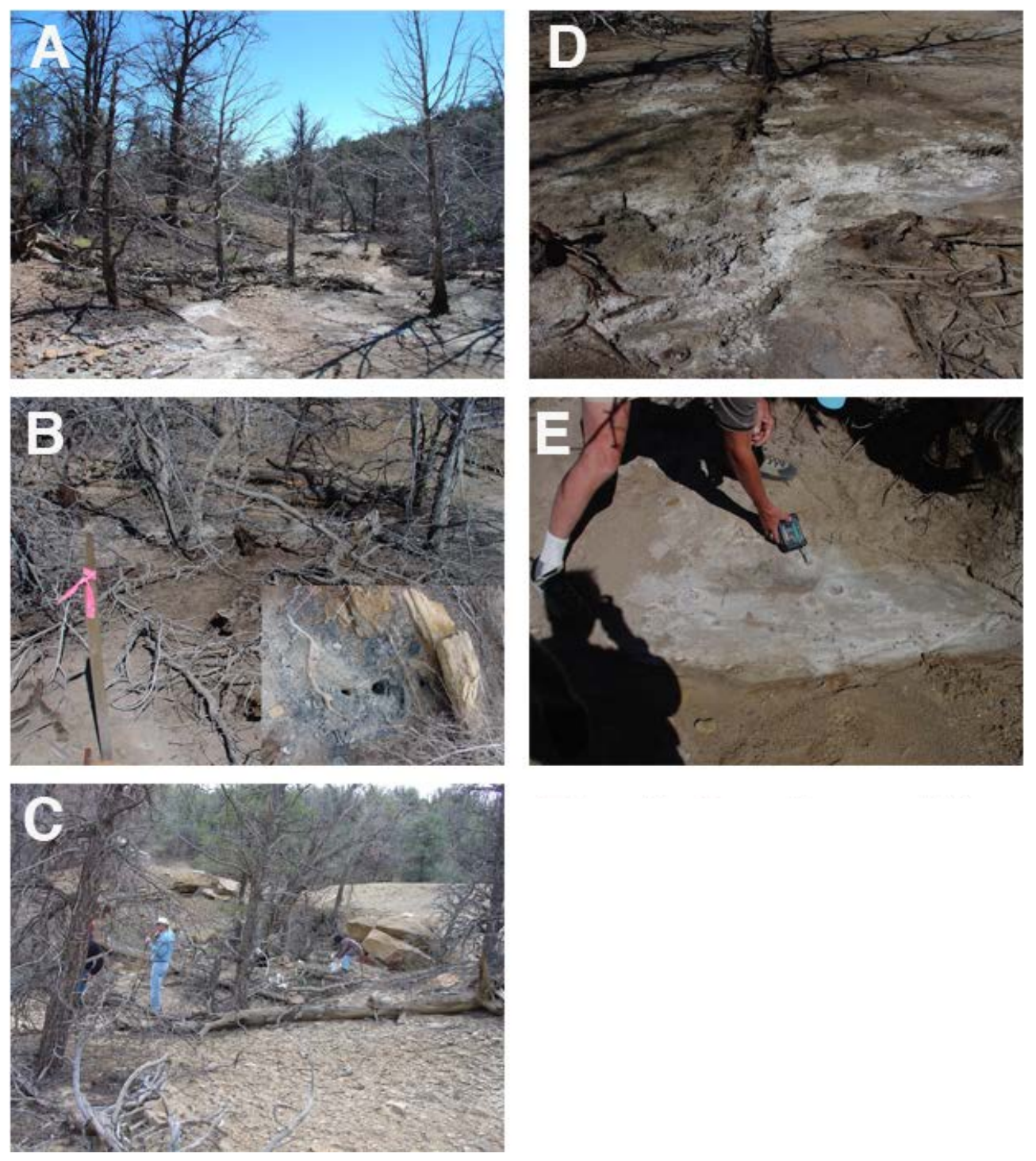

Figure 10. Natural gas seeps on the western margin of the San Juan Basin southwest of Durango, Colorado. We recorded sulfur dioxide in some seep locations. In some cases, gas seeping out of the ground was focused and such force that it formed small holes in the soil. Adjacent coalbed methane wells contained appreciable amounts of hydrogen sulfide as well. 


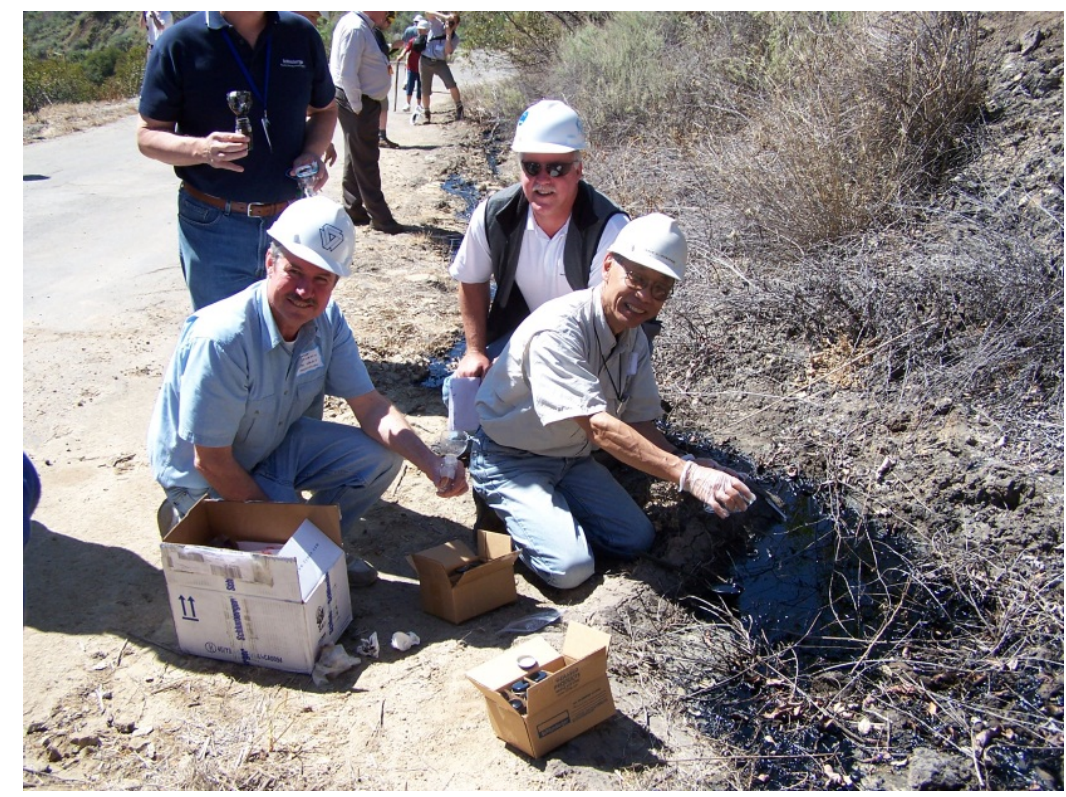

Figure 1. Naturally occurring oil seeps east of Los Angeles. The samples taken from this location included partially biodegraded oil and connate formation water.

Table 1. Major sampling trips at methane seeps and other relevant sites

\begin{tabular}{|l|l|l|}
\hline Date & Location* & Samples Collected \\
\hline April 12, 2004 & SFTC & $\begin{array}{l}\text { Creek Water, Creek Sediment and } \\
\text { Mud, Soil - surface and subsurface }\end{array}$ \\
\hline September 15, 2005 & SFTC & $\begin{array}{l}\text { Creek Water, Creek Sediment and } \\
\text { Mud, Soil - surface and subsurface }\end{array}$ \\
\hline September 19, 2005 & Ute & $\begin{array}{l}\text { Soil - surface and subsurface from } \\
\text { seep areas (see Fig. 4) } \\
\text { Well water from CBM wells "N 37 W } \\
107 \text { " and "32 N 10 W sect J" }\end{array}$ \\
\hline October 18, 2006 & SFTC & $\begin{array}{l}\text { Creek Water, Creek Sediment and } \\
\text { Mud, Soil - surface and subsurface }\end{array}$ \\
\hline xx-xx-xxxx & Black Marsh & Water and Sediment \\
\hline April 5, 2007 & La Brea & Heavy oil and water from seep \\
\hline
\end{tabular}

*SFTC: South Fork Texas Creek (SFTC) site, near Bayfield, CO, owned by BP-Amoco, Inc. *Ute: The Southern Ute Indian Tribe near Ignacio, CO

*Black Marsh: Chesapeake Bay Black Marsh in Virginia

*La Brea: Natural oil seep east of Los Angeles 
The primary goal of this research phase was to isolate anaerobic methane oxidizers (AMO), so the sample collection efforts focused on shallow, subsurface samples, which would most likely be anaerobic. The sample collection design was based on the published reports that the anaerobic methane oxidizing (AMO) microorganisms are oxygen sensitive, but could tolerate low levels of oxygen. So, we considered the possibility that novel anaerobic methane oxidizers that tolerate oxygen or switch between aerobic and anaerobic modes of methane oxidation could also be present. we also collected surface samples as well.

Therefore at the SFTC site we targeted two areas:

(1) Land area where grass cover has been lost due to natural gas emission (Figures 8A to D). During the winter sample collection the seep locations were more readily visible, because they melted the thin snow cover and the snow cover amplified the sound of exiting gas as it sometimes lifted the snow cover. We collected soil samples from the surface and subsurface (0.5-1 $\mathrm{ft}$ below of the ground) at this area.

(2) Texas Creek which runs through this property: Almost all throughout the year, including in winter, gas bubbles through the creek sediment and water at high volumes (Figures. 9A-G). We collected water, sediment and their mixtures. After collection, the samples were placed inside serum bottles (Balch et al, 1976; Mukhopadhyay et al. 1999). Immediately after that each bottle was sealed with a robber stopper and aluminum crimp (Balch et al, 1976; Mukhopadhyay et al. 1999) and the contents were made anaerobic via evacuation and placed under methane $+\mathrm{N}_{2}(70: 30 \mathrm{v} / \mathrm{v}, 5 \mathrm{psi})$ or methane $+\mathrm{N}_{2}+\mathrm{CO}_{2}$ (70:20:10, v/v; 5 psi) using the system shown in see Figure 12. This step helped to maintain the integrity of the sample and minimized exposure to air (oxygen). From the Southern Ute Indian Tribe gas fields we collected surface and subsurface soil samples (Figures $10 \mathrm{~A}$ to E). The sediment and water samples from Chesapeake Bay Black Marsh were also collected in the same manner. The sampling at naturally-occurring oil and methane seeps was performed during a geological field trip as the opportunity presented 
itself. A plastic container was completely filled $2 / 3^{\text {rd }}$ way with the sample and closed with a lead. All samples were brought to the laboratory of Dr. Biswarup Mukhopadhyay at the Virginia Bioinformatics Institute at the Virginia Tech within 2-3 days of collection either via an express delivery service.

\section{Development of Stable Anaerobic Methane Oxidizing Enrichments}

The enrichment mixtures were set up in rubber stopper and aluminum crimp sealed 50$250 \mathrm{ml}$ serum bottles following the standard techniques that have been used for the enrichment and cultivation of methane forming archaea or methanogens (Balch et al, 1976; Belay et al. 1990; Mukhopadyhyay et al 1992) and anaerobic methane oxidizers (Boetis et al 2000; Nanhaus et al 2007; Raghoebarsing et al, 2006). The mixtures contained one or more of the materials described above and laboratory made or synthetic sterile media. The synthetic media were formulated from a low-salt medium that has been extensively used in work with the methanogens (Balch et al., 1976) and it contained trace metals that support the growth of a wide range of anaerobic microorganisms (Balch et al, 1976; Mukhopadhyay et al. 1999). When needed, it was also supplemented with $\mathrm{NaCl}$ to match the salinity of the site samples. For every set, mixtures with and without vitamins were prepared (Balch et al, 1976; Mukhopadhyay et al. 1999). The vitamin stock solution was sterilized via filtration and other stock solutions were autoclaved prior to their use. Following were the compositions of the primary enrichment mixtures.

A. I and II. Surface soil sample from SFTC site +10 volumes of synthetic medium (+/- vitamins)

B. III. Surface soil sample from SFTC site +10 volumes of water from the creek on the same property

C. IV-V. Sub-surface soil sample from SFTC site +10 volumes of synthetic medium (+/- vitamins)

D. VI. Sub-surface soil sample from SFTC site +10 volumes of creek water 
E. VII and VIII. Sediment or mud from the creek +10 volumes of synthetic medium (+/- vitamins)

F. IX. Sediment or mud from the creek +10 volumes of creek water

G. X: Creek water

H. XI and XII. Surface soil sample from the Southern Ute Indian Tribe's natural gas field +10 volumes of synthetic medium (+/- vitamins)

I. XIII. Surface soil sample from the Southern Ute Indian Tribe's natural gas field + 10 volumes of water from a coal-bed methane well from the same property

J. XIV and XV. Sub-surface soil sample from the Southern Ute Indian Tribe's natural gas field +10 volumes of synthetic medium (+/- vitamins)

K. XVI. Sub-surface soil sample from the Southern Ute Indian Tribe's natural gas field +10 volumes of CBM well water

L. XVII. CBM well water that was used above.

M. XVIII-XIX: Sediment from Chesapeake Bay Black Marsh + synthetic medium (+/- vitamins

N. XX: Sediment from Chesapeake Bay Black Marsh + Water from Chesapeake Bay Black Marsh

O. XXI: Water from Chesapeake Bay Black Marsh

P. XXII AND XXIII. La Brea Tar Pits sample + 10 volumes of synthetic medium (+/- vitamins)

For each of the above 23 mixtures additional variations were generated by providing the following three supplements, which served as electron acceptors for methane oxidation in the absence of oxygen (Boetis et al 2000; Nanhaus et al 2007; Raghoebarsing et al, 2006): sodium sulfate, 20-30 mM; sodium nitrate, 2-4 mM; and sodium nitrite, 0.1-0.5 $\mathrm{mM}$.

The enrichment mixtures in the serum bottles were placed under a gas atmosphere of $\mathrm{N}_{2}$ + methane $\left(90: 10 \mathrm{v} / \mathrm{v}\right.$ or $\mathrm{N}_{2}+\mathrm{CO}_{2}+$ methane, 72:18:10) and then incubated at room temperature $\left(25^{\circ} \mathrm{C}\right)$ and at a higher temperature (such as $40{ }^{\circ} \mathrm{C}$ ). 


\section{Evaluation of Enrichments for Methane Oxidation Potential}

The concentrations of methane in the headspaces of the sealed bottles containing the enrichment mixtures were monitored at regular intervals for determining whether methane was being consumed. For this purpose, a sample of the head space of each culture bottle was assayed for methane by use of a gas chromatograph (Shimadzu Corporation, Model GC 2010) fitted with a flame ionization detector and a $0.53 \mathrm{~mm} \times 30$ m Supelco Carboxen ${ }^{\circledR}-1010$ PLOT column (Sigma-Aldrich Co.). The column, detector, and injector were maintained at 100,150 , and $150{ }^{\circ} \mathrm{C}$, respectively. The carrier gas $\left(\mathrm{N}_{2}\right)$ flow rate was $1 \mathrm{ml} / \mathrm{min}$. A methane standard (Matheson Tri-Gas, Montgomeryville, PA) was used for calibration. Whenever a primary culture mixture consumed methane (exhibiting lowered methane concentration in the headspace), it was used as inoculum for starting a second stage culture. Synthetic media with and without $\mathrm{NaCl}$ and/or vitamin supplements as well as appropriate external electron acceptors such as sulfate, nitrate and nitrite as indicated under Task 4 were used for the transfer cultures. If the second stage culture showed methane consumption, the transfers were repeated several times with a goal of obtaining a stable mixed culture that consistently consumed methane.

\section{$\underline{\text { RESULTS OF MICROBIAL INVESTIGATIONS }}$}

In our investigations we screen more than 500 enrichments and never found a convincing case of anaerobic methane oxidation. In all cases, as evident from visual and microscopic observations, the early stage enrichments contained microbial cells. However, as the levels of the readily substrates that were present in the environmental samples were extensively lowered through serial transfers, the numbers of cells in the enrichments sharply dropped and finally these were eliminated. While the results were disappointing we acknowledge that AOM microorganisms are predominantly found in marine habitats and grow poorly under most laboratory conditions. 
To examine whether our samples contained aerobic methane oxidizers, we generated enrichments with methane and oxygen as substrates and some of the enriched microorganisms were characterized in pure cultures. We isolated several bacterial strains from aerobic methane oxidizing enrichments. For this task we used solid media that were solidified with Gelrite ${ }^{\circledR}$ (CP Kelco U.S) and contained the components that were present in the enrichments serving as the inocula. The isolates were purified through restreaks. Some of these were hard to cultivate in liquid cultures and this observation led to the hypotheses that they were someway dependent on the solid media, deriving nutrients or gaining from attachments. From the cells either retrieved from the solid medium surface or grown in liquid cultures, total genomic DNA was isolated for several isolates via standard methods (Mukhopadhyay and Purwantini, 2000; Mukhopadhyay et al 1995). Using these DNA samples as templates 16S rRNA genes were PCR amplified by use of bacteria and archaea specific primers (archaea: $27 \mathrm{f}$ and 1492r or 1525r; bacteria: A8f or A21f and 1492r or 1525r)(Lane 1991) and Taq DNA polymerase and cloned into the plasmid pGEM-T (Promega Corp., Madison, WI). Then the cloned amplicons were sequenced. Finally, from BLAST analyses of the amplicon sequences we obtained the tentative identities of the isolates. Following are the tentative identities of the predominant isolates that were obtained from the South Fork Texas Creek (SFTC) site.

Table 2. Microorganisms identified

Methanotroph:

Flectobacillus speluncae

Methylomonas sp. KSPIII

Methylotroph:

Methylophilus leisingeri

A non-methanotroph often found in methane oxidizing microbial consortia (5):

Flavobacterium sp. EP131

Janthinobacterium lividum

Falvobacterium xinjiangense

A non-methanotroph that enhances methane oxidizing activity of other methanotrophic bacteria (4)

Variovorax paradoxus 


\section{Non-methanotroph, heterotroph \\ Rhizobium daejeonense \\ Pseudomonas corrugata}

\section{Unknown}

Uncultured bacterium clone W-Btb7_09

Uncultured bacterium clone rRNA330

Uncultured bacterium clone rRNA222

Uncultured bacterium clone rRNA290

Uncultured bacterium clone rRNA123

Agricultural soil bacterium clone SC-I-93

\section{POSSIBLE APPLICATION OF TECHNOLGY}

Direct Atmospheric concentrations of methane have been increasing at approximately 0.6 percent per year (Steele et al., 1992) and have more than doubled over the past 100 years (IPCC, 1990). Methane is one of the principal greenhouse gases, second only to carbon dioxide in its contribution to potential global warming. The research conducted under this grant sought to collect previously unidentified methanotrophs and other microbes from naturally occurring methane seeps that could potentially reduce non-carbon dioxide gas emissions and prevent mine explosions through: (1) direct application to abandoned rooms in underground mines via application directly to coal surfaces; (2) injection of anaerobic microbes into gob-gas collection well systems in front of mining operations; (3) underground applications employing shallow wells or alternative cost-effective methods of injecting microbes into coaly-soils and coals, thereby reducing methane seepage to outcrops and subcrops; (4) development of efficient methane oxidation in biofilters that may be more cost-effective and efficient in removing low concentrations of methane in mine ventilation systems under suboxic or anoxic conditions; (5) construction of biofilter walls that isolate and control methane emissions from abandoned parts of underground mines with high methane concentrations; and (6) enhancement of methane oxidation in aerobic, suboxic, or anaerobic conditions. The inability to confirm the presence of anaerobic methanotrophs in this project coupled with time and financial limitations limits the discussion on 
technological applications. However, should terrestrial methanotrophs be isolated, there may be opportunities that might present themselves.

Unfortunately, the inability to find anaerobic methanotrophs negated the various possible applications of the technology. However, some opportunities may be possible in the future if the correct microbes are isolated and some of these technologies are discussed herein. The closest real-world application is a combination of methane drainage in the shallow subsurface coupled with aerobic methanotrophs. LT Environmental, Inc. recently tested passive and active (using vacuum blower) vapor extraction systems to extract vapors from a PVC gathering systems buried three feet below the surface in the methane seep areas. These systems were designed to extract vapors (methane) or inject air. Active venting that removed methane and introduces oxygen into the subsurface reduced the methane emissions in some cases up to 40 feet away from the PVC test site. Combining the vapor extraction with aerobic methanotrophs at depth could more efficiently reduce methane emissions.

Recovery of methane in front of coal mining operations has proven successful in many areas, but has limited potential in other areas that have relatively lower gas contents and/or when the price of natural gas is too low. The presence of hydrogen sulfide at some methane seeps and underground coal mines indicates the presence of anaerobic microbial populations. The presence of hydrogen sulfide also indicates that methane is being utilized in the microbial processes and that the potential exists for discovering anaerobic methanotrophs. Once the shallow microbial process are understood, it may be possible to increase methane consumption rates, while simultaneously reducing hydrogen sulfide emissions by changing microbial population dynamics.

Some underground coal mines encounter high hydrogen sulfide concentrations in pockets while mining. Even the presence of trace amounts of hydrogen sulfide can shut down mining operations and present a safety hazard to miners. Additionally, roof stability problems are created when steel roof bolts are corroded within days or even hours of exposure to even small amounts of hydrogen sulfide. A recent study determined that a chemical infusion process utilizing specially developed solutions sprayed on coal at the front of mining operations could change microbial processes and reduce hydrogen sulfide 
generation; no attempt was made to stop hydrogen sulfide generation before the coal was mined (Gilles et al., 2000).

The use of anaerobic microbial consortia in mining operations is important because additional oxygen cannot be injected into the coal seams to support aerobic methanotroph populations that consume methane. Under some conditions oxygen and coal may spontaneously combust and start an underground coal fire. Therefore, the discovery of methanotrophs that survive in suboxic or anaerobic conditions would have a significant advantage over aerobic methanotrophs in the subsurface, particularly in mines in which significant amounts of methane have accumulated in times when the mine is not active. Anaerobic conditions probably occur very near the surface within a few feet or tens of feet of the outcrop, because the aerobic microbial populations remove the oxygen from the system very quickly. Coal contains oxygen organically bound in the coal structure. Therefore, it may be possible for this oxygen to be used by microaerophillic microbes for methane oxidation. We will also predict if known methanotrophic microorganisms (bacteria and yeast) have the ability to utilize the inherent oxygen in coals to metabolize methane.

Application of the previously unidentified microbes can be performed in several ways to achieve different objectives in both coal mining operations and areas of concentrated methane seeps. Abandoned rooms of underground mines are often sealed off from active mining areas to increase air availability for the working mine areas. Methane will accumulate in these rooms over a period of time creating an explosive hazard or, if ventilated, the release of a greenhouse gas. The naturally occurring, coaladapted microbes can be dispersed in the area where methane buildup may occur and the organisms will consume methane. Alternatively, the methanotrophs may be used as part of a biofilter system that will allow methane-saturated air to pass through the microbial filter, thereby removing the methane. Temporary walls made up of these filters could be readily constructed and placed in areas that do not have mining activity or where ventilated mine air is expelled. Finally, the microorganisms and nutrients could be injected into existing gob gas collection systems consisting of vertical or horizontal wells and holes, which have been shut in and abandoned due to low gas prices and/or other economic factors. 
Finally, in addition to reducing non-carbon dioxide greenhouse gases and the possibility of mine explosions, the methanotrophs identified and cultured in this study, when combined with other fermentative microbial cultures, may produce valuable oxychemicals (acetate, lactate, acetaldehyde, etc) that are desirable and valuable commodities. For example, methane oxidation can yield methanol that is commonly used as a building block for other chemicals or as an alternative fuel (Chenge and Kung, 1994). Methanotrophs do not pose any known biologic hazards, and their application to reducing methane concentration in coal mines would improve the safety of the coal miners.

One of the objectives in this research was to develop an understanding of the metabolic pathway used by the microorganisms for the oxidation of methane is essential for the design and scale-up of a process designed to mitigate greenhouse gas emissions. Our goal was to identify the various compounds that are formed in the enrichment and in pure cultures noting that these compounds may be end products or transient products formed during microbial processes. From these pieces of information, we had hoped to be able to construct the metabolic pathway for methane oxidation. Unfortunately, the detailed characterization of bioconversion pathways is often a lengthy and tedious process and knowing this our goal was to obtain preliminary information on the metabolic pathways due to time limitations and budgetary restrictions. Unfortunately, the economics of applying the microbial technology could not be assessed at this time because the microbial enrichments could not be established. 


\section{REFERENCES}

Apolinario, E.A. and K.R. Sowers. 1996. Plate colonization of Methanococcus maripaludis and Methanosarcina thermophila in a modified canning jar. FEMS Microbiol Lett. 145: 131-137.

Balch, W. E., and R. S. Wolfe. 1976. New approach to the cultivation of methanogenic bacteria: 2-mercaptoethanesulfonic acid (HS-CoM)-dependent growth of Methanobacterium ruminantium in a pressureized atmosphere. Appl Environ Microbiol 32:781-91.

Belay, N., B. Mukhopadhyay, E. Conway de Macario, R. Galask, and L. Daniels. 1990. Methanogenic bacteria in human vaginal samples. J Clin Microbiol 28:1666-8.

Boetius, A., K. Ravenschlag, C. J. Schubert, D. Rickert, F. Widdel, A. Gieseke, R. Amann, B. B. Jorgensen, U. Witte, and O. Pfannkuche. 2000. A marine microbial consortium apparently mediating anaerobic oxidation of methane. Nature 407:623-6.

Flagan, S., W. K. Ching, and J. R. Leadbetter. 2003. Arthrobacter strain VAI-A utilizes acyl-homoserine lactone inactivation products and stimulates quorum signal biodegradation by Variovorax paradoxus. Applied and Environmental Microbiology 69:909-916.

Hesselsoe, M., S. Boysen, N. Iversen, L. Jorgensen, J. C. Murrell, I. McDonald, S. Radajewski, H. Thestrup, and P. Roslev. 2005. Degradation of organic pollutants by methane grown microbial consortia. Biodegradation 16:435-48.

Houghton, J.T., Meira, F., Callander, B.A., Harris, N, Kattenberg, A., Maskel, K., 1996, Climate Change 1995, published by Cambridge University Press.

IPCC, 1990, Climate Change: The IPCC Scientific Assessment. Report prepared for Intergovernmental Panel on Climate Change (IPCC) by Working Group 1.

IPCC, 1995, Climate Change 1995, Summary for Policymakers and Working Group I report.

Juretschko, S., G. Timmermann, M. Schmid, K.H. Schleifer, A. Pommerening-Roser, H.P. Koops, and M. Wagner.1998. Combined molecular and conventional analyses of nitrifying bacterium diversity in activated sludge: Nitrosococcus mobilis and Nitrospira-like bacteria as dominant populations. Appl. Environ. Microbiol. 64:3042-3051.

Kruger, D. and Schultz, 1996, A guide for methane mitigation projects: Gas to energy at coal mines; Draft Report, February 1996, variously paginated. 
Lane, D. J. 1991. 16S/23S rRNA sequencing. Nucleic acid techniques in bacterial systematics, p. 115-175. In E. Stackebrandt and M. Goodfellow (ed.). John Wiley and Sons, New York, NY.

Mukhopadhyay, B., E. F. Johnson, and R. S. Wolfe. 1999. Reactor-scale cultivation of the hyperthermophilic methanarchaeon Methanococcus jannaschii to high cell densities. Appl Environ Microbiol 65:5059-65.

Mukhopadhyay, B., and E. Purwantini. 2000. Pyruvate carboxylase from Mycobacterium smegmatis: stabilization, rapid purification, molecular and biochemical characterization and regulation of the cellular level. Biochim Biophys Acta 1475:191-206.

Mukhopadhyay, B., E. Purwantini, E. C. De Macario, and L. Daniels. 1992. Characterization of Methanosarcina strain isolated from goat feces, and that grows on H2-CO2 only after adaptation. Curr. Microbiol. 23:165-173.

Mukhopadhyay, B., E. Purwantini, T. D. Pihl, J. N. Reeve, and L. Daniels. 1995. Cloning, sequencing, and transcriptional analysis of the coenzyme F420dependent methylene-5,6,7,8-tetrahydromethanopterin dehydrogenase gene from Methanobacterium thermoautotrophicum strain Marburg and functional expression in Escherichia coli. J Biol Chem 270:2827-32.

Nauhaus, K., M. Albrecht, M. Elvert, A. Boetius, and F. Widdel. 2007. In vitro cell growth of marine archaeal-bacterial consortia during anaerobic oxidation of methane with sulfate. Environ Microbiol 9:187-96.

Pernthaler,A., J. Pernthaler, and R. Amann. 2002. Fluorescence in situ hybridization and catalyzed reporter deposition for the identification of marine bacteria. Appl Environ Microbiol. 68:3094-3101.

Raghoebarsing, A. A., A. Pol, K. T. van de Pas-Schoonen, A. J. Smolders, K. F. Ettwig, W. I. Rijpstra, S. Schouten, J. S. Damste, H. J. Op den Camp, M. S. Jetten, and M. Strous. 2006. A microbial consortium couples anaerobic methane oxidation to denitrification. Nature 440:918-21.

Sapoundjiev, H., Aube, F., Hosatte, S. Gauthier, J.E.D., and Trottier, R., 1999, Economic heat recovery and greenhouse gas elimination from ventilation air of underground coal mines; International Coalbed Methane Symposium, The University of Alabama Continuing Education, Tuscaloosa, Alabama, May 3-7, 1999 p. 269278 
Scott, A.R. Kaiser, W. R., and Ayers, W. B., Jr., 1994, Thermogenic and secondary biogenic gases, San Juan Basin, Colorado and New Mexico-implications for coalbed gas producibility: American Association of Petroleum Geologists Bulletin, v. 78, no. 8, p. 1186-1209.

Scott, A. R., 1996, Coalification, cleat development, coal gas composition and origins and gas content of Williams Fork coals in the Piceance Basin: in Tyler et al, Geologic and hydrologic controls critical to coalbed methane procucibility and resource assessment: Williams Fork Formation, Piceance Basin, Northwest, Colorado; GRI Topical Report GRI-95/0532 p. 220-251.

Steele, L.P., Dlugokemcky, E. J., Lang, P.M., Tans, P.P., Margin, R.C., and Masarie, K.A., 1992, Slowing down the global accumulation of atmospheric methane during the 1980's; Nature, v. 358, July 23, 1992 